JEVTE: Journal of Electrical Vocational Teacher Education, Vol. 1, No. 2, Nopember 2021

\title{
PENGEMBANGAN MEDIA PEMBELAJARAN MULTIMEDIA INTERAKTIF LECTORA INSPIRE MATA PELAJARAN PEKERJAAN DASAR ELEKTROMEKANIK
}

\author{
Aprilia Rahmi ${ }^{1}$, Baharuddin ${ }^{2}$ \\ 1,2Pendidikan Teknik Elektro Fakultas Teknik Unimed \\ 1. apriliarahmi97@gmail.com, ${ }^{2}$ baharuddin.bah@gmail.com
}

\begin{abstract}
Abstrak
Tujuan dari penelitian ini adalah mengembangkan media pembelajaran yang layak untuk memudahkan guru dan peserta didik dalam proses belajar mengajar. Penelitian ini adalah jenis penelitian pengembangan (Research and Development) dengan model pengembangan $4 D$ yang dikembangkan oleh Thiagaradjan. Model 4D terdiri dari 4 tahap, yaitu: 1) Define (Pendefinisian), 2) Design (Perancangan), 3) Develop (Pengembangan), 4) Disseminate (Penyebaran). Tahap penyebaran (disseminate) tidak dilakukan dikarenakan waktu serta kondisi yang kurang memungkinkan, dan pada tahap pengembangan (develop) tujuan penelitian telah tercapai dimana media pembelajaran yang dikembangkan telah diketahui sejauh mana kelayakannya untuk diterapkan dalam proses pembelajaran. Tingkat kelayakan media pembelajaran diketahui dari hasil validasi oleh ahli materi dan ahli media. Dari validasi yang telah dilakukan, didapatkan bahwa ahli materi memberikan nilai sebesar 4,58 dan ahli media sebesar 4,57 dimana nilai tersebut mencapai indikator kelayakan Sangat Baik. Dengan demikian pengembangan media pembelajaran ini sangat baik dilakukan karena telah diuji kelayakannya oleh para ahli.
\end{abstract}

\section{Kata Kunci: Pengembangan Media Pembelajaran, Model Pengembangan 4D, Lectora Inspire}

\begin{abstract}
The aims of this research is to develop a viable learning medium to facilitate teachers and learners in the teaching and learning process. This research is a type of research development (Research and Development) with a $4 \mathrm{D}$ development model developed by Thiagaradjan. The $4 \mathrm{D}$ model consists of 4 stages, namely: 1) Define (Defining), 2) Design (Design), 3) Develop (Development), 4) Disseminate (Deployment). The disseminate stage is not carried out due to time and conditions that are less likely, and at the stage of development (develop) research objectives have been achieved where the learning media developed has been known the extent of its feasibility to be applied in the learning process. The level of feasibility of learning media is known from the results of validation by material experts and media experts. From the validation that has been done, it was found that material experts gave a value of 4.58 and media experts of 4.57 where the value reached the excellent eligibility indicator. Thus the development of this learning media is very well done because it has been tested for feasibility by experts.
\end{abstract}

Keywords: Learning Media Development, 4D Development Model, Lectora Inspire

\section{PENDAHULUAN}

Pekerjaan Dasar Elektromekanik atau PDE merupakan materi pelajaran siswa SMK jurusan TITL (Teknik Instalasi Tenaga Listrik) yang menjelaskan tentang metode dan pengenalan alat tangan kerja, salah satunya ialah pembuatan box panel listrik dari pelat logam. Alokasi waktu dalam pelajaran ini adalah 68 Jam Pelajaran dimana 1 jam pelajaran $=45$ menit. Mata Pelajaran ini merupakan pelajaran pokok dan mendasar dalam program keahlian yang diajarkan di kelas X SMK, khususnya Teknik Instalasi Penerangan Tenaga Listrik yang didalam nya terdapat materi pengenalan alat dan bahan kerja listrik, keselamatan dan kesehatan kerja, dan materi dasar lainnya sebagai pedoman dalam melanjutkan keahlian di bidang teknik tenaga listrik.

Dalam penyampaian materi pelajaran, masalah yang sering terjadi adalah kurangnya perhatian siswa kepada penjelasan yang disampaikan guru yang disebabkan oleh berbagai hal, diantaranya cara menyampaikan yang kurang jelas, cara penyampaian yang kurang menarik, ukuran 
kelas yang besar sehingga kondisi kelas tidak kondusif sehingga penyampaian materi dengan metode ceramah yang dilakukan kurang didengarkan dan dipahami oleh siswa.

Selain itu, hasil dari observasi yang dilakukan di SMK Negeri 1 Percut Sei Tuan juga didapatkan data bahwa sekolah juga menyediakan fasilitas LCD Proyektor yang digunakan untuk menampilkan materi pembelajaran. Jadi, selain menggunakan metode ceramah guru juga menggunakan media powerpoint untuk presentasi. Tetapi masih banyak juga siswa yang tidak memperhatikan penjelasan guru saat proses pembelajaran Pekerjaan Dasar Elektromekanik, dikarenakan siswa bosan atau kurang tertarik dengan media pembelajaran powerpoint yang digunakan oleh guru.

Software Lectora Inspire merupakan salah satu software yang dapat digunakan untuk membuat media pembelajaran interaktif. Lectora Inspire saat ini banyak diterapkan di beberapa lingkungan instansi pendidikan karena sangat mudah dalam penggunaannya untuk menciptakan media pembelajaran interaktif. Lectora Inspire dapat digunakan sebagai salah satu alternatif software untuk membuat media pembelajaran yang menarik bagi siswa. Fitur-fitur yang disediakan Lectora Inspire sangat memudahkan pengguna pemula untuk membuat multimedia (audio dan video) pembelajaran.

Penelitian yang dilakukan oleh Mega Astutik dan Puput Wanarti dalam jurnal Pendidikan Teknik Elektro, Universitas Negeri Surabaya 2016 yang berjudul "Pengembangan Media Pembelajaran Multimedia Interaktif Berbantuan Software Lectora Inspire untuk Meningkatkan Hasil Belajar pada Pelajaran teknik Listrik di SMK Negeri 2 Surabaya", menyatakan bahwa hasil penelitian yang diperoleh adalah untuk hasil respon siswa terhadap media pembelajaran didapatkan hasil dari berbagai aspek, yaitu: (1) hasil kelayakan produk memperoleh persentase $87,37 \%$ dan masuk dalam kriteria sangat layak, (2) hasil respon siswa memperoleh persentase $91,72 \%$ dan masuk dalam kriteria sangat baik, (3) ketuntasan hasil belajar siswa memperoleh persentase 94,87\% serta nilai rata-rata kelas sebesar 3,35 yang dilambangkan dengan huruf $\mathrm{B}+$.

Penelitian yang dilakukan oleh Mega Astutik dan Puput Wanarti dalam jurnal Pendidikan Teknik Elektro, Universitas Negeri Surabaya 2016 yang berjudul "Pengembangan Media Pembelajaran Multimedia Interaktif Berbantuan Software Lectora Inspire untuk Meningkatkan Hasil Belajar pada Pelajaran teknik Listrik di SMK Negeri 2 Surabaya”, menyatakan bahwa hasil penelitian yang diperoleh adalah untuk hasil respon siswa terhadap media pembelajaran didapatkan hasil dari berbagai aspek, yaitu: (1) hasil kelayakan produk memperoleh persentase $87,37 \%$ dan masuk dalam kriteria sangat layak, (2) hasil respon siswa memperoleh persentase $91,72 \%$ dan masuk dalam kriteria sangat baik, (3) ketuntasan hasil belajar siswa memperoleh persentase 94,87\% serta nilai rata-rata kelas sebesar 3,35 yang dilambangkan dengan huruf $\mathrm{B}+$.

\section{Pengertian Pembelajaran}

Belajar adalah suatu proses yang kompleks yang terjadi pada semua orang dan berlangsung seumur hidup, sejak dia masih bayi hingga ke liang lahat nanti. Salah satu pertanda bahwa seseorang telah belajar adalah adanya perubahan tingkah laku dalam dirinya. Perubahan tingkah laku tersebut menyangkut baik perubahan yang bersifat pengetahuan (kognitif) dan keterampilan (psikomotorik) maupun yang menyangkut nilai dan sikap (afektif) (Arief S, Sadiman, 2009: 2).

Cronbach (dalam Riyanto, 2014) menyatakan bahwa belajar itu merupakan perubahan perilaku sebagai hasil dari pengalaman. Menurut Cronbach bahwa belajar sebaik-baiknya adalah dengan mengalami sesuatu yaitu menggunakan pancaindra. Dengan kata lain, bahwa hasil belajar adalah suatu cara mengamati, membaca, meniru, mengintimasi, mencoba sesuatu, mendengar dan mengikuti arah tertentu.

Trianto (2010:17) mengatakan bahwa pembelajaran merupakan aspek kegiatan manusia yang kompleks, yang tidak sepenuhnya dapat dijelaskan. Pembelajaran secara sederhana dapat diartikan sebagai produk interaksi berkesinambungan antara pengembangan dan pengalaman hidup. Sedangkan pembelajaran dalam makna kompleks adalah usaha sadar dari seorang guru untuk membelajarkan siswanya yaitu mengarahkan interaksi siswa dengan sumber belajar lainnya untuk mencapai tujuan yang diharapkan.

\section{Media Pembelajaran}

Menurut Sadiman, Arief. dkk (2009:6) kata media berasal dari bahasa Latin dan merupakan bentuk jamak dari kata medium yang secara harfiah berarti perantara atau pengantar. Media adalah segala sesuatu yang dapat digunakan untuk menyalurkan pesan dari pengirim ke penerima sehingga 
dapat merangsang pikiran, perasaan, perhatian dan minat serta perhatian siswa sedemikian rupa sehingga proses belajar terjadi.

Pada mulanya media hanya dianggap sebagai alat bantu mengajar guru (teaching aids). Alat bantu yang dipakai adalah alat bantu visual, yaitu gambar, model, objek, dan alat-alat lain yang dapat memberikan pengalaman konkrit, motivasi belajar serta mempertinggi daya serap dan retensi belajar siswa. Namun sayang, karena terlalu memusatkan perhatian pada alat bantu visual yang dipakainya, orang kurang memperhatikan aspek desain, pengembangan pembelajaran, produksi, dan evaluasinya (Sadiman, Arief. dkk, 2009:7)

Hamalik (dalam Arsyad, 2011:15) mengemukakan bahwa pemakaian media pembelajaran dalam proses belajar mengajar dapat membangkitkan keinginan dan minat yang baru, membangkitkan motivasi dan rangsangan kegiatan belajar, dan bahkan membawa pengaruh-pengaruh psikologis terhadap siswa.

Penggunaan media pembelajaran pada tahap orientasi pembelajaran akan sangat membantu keefektifan proses pembelajaran dan penyampaian pesan dan isi pelajaran pada saat itu. Selain membangkitkan motivasi dan minat siswa, media pembelajaran juga dapat membantu siswa meningkatkan pemahaman, menyajikan data dengan menarik dan terpercaya, memudahkan penafsiran data, dan memadatkan informasi. Beberapa manfaat dari penggunaan media pembelajaran sebagai berikut:

a. Membuat konkret konsep-konsep yang abstrak. Konsep-konsep yang dirasa masih bersifat abstrak dan sulit dijelaskan secara langsung kepada siswa bisa dikonkritkan atau disederhanakan melalui pemanfaatan media pembelajaran sehingga siswa dengan mudah untuk memahami materi pembelajaran.

b. Dapat menghadirkan objek-objek yang terlalu berbahaya atau sukar ke dalam lingkungan belajar.

c. Dapat menghadirkan objek-objek yang terlalu besar atau kecil ke dalam lingkungan belajar. Misalnya guru akan menunjukkan pesawat udara atau bakteri melalui media gambar.

d. Dapat memperlihatkan gerakan yang terlalu cepat atau lambat.

Menurut Rusman (2013:173-177) media pembelajaran dapat diklasifikasikan berdasarkan sifat, jangkauan dan teknik pemakainya.

a. Dari sifatnya, media dapat dibagi kedalam :

1) Media auditif, yaitu media yang hanya dapat didengar saja atau media yang memiliki unsur suara.

2) Media visual, yaitu media yang hanya dapat dilihat saja, tidak mengandung unsur suara.

3) Media audiovisual, yaitu jenis media yang selain mengandung unsur suara juga mengandung unsur gambar yang bisa dilihat.

b. Dari kemampuan jangkauannya, media dapat pula dibagi ke dalam:

1) Media yang memiliki daya input yang luas dan serentak.

2) Media yang memiliki daya input yang terbatas oleh ruang dan waktu.

c. Dari cara atau teknik pemakaiannya, media dapat dibagi kedalam :

1) Media yang diproyeksikan.

2) Media yang tidak diproyeksikan.

Menurut Robin dan Linda (dalam Benardo, 2011), multimedia interaktif adalah alat yang dapat menciptakan presentasi yang dinamis dan interaktif, yang mengkombinasikan teks, grafik, animasi, audio dan gambar video. Sedangkan menurut Hofstetter (dalam Benardo, 2011), multimedia interaktif adalah pemanfaatan komputer untuk membuat dan menggabungkan teks, grafik, audio, gambar bergerak (video dan animasi) dengan menggabungkan link dan tool yang memungkinkan pemakai melakukan navigasi, berinteraksi, berkreasi dan berkomunikasi.

\section{Lectora Inspire}

Software lectora inspire merupakan perangkat lunak Authoring Tool untuk pengembangan konten yang dikembangkan oleh Trivantis Corporation, sebuah perusahaan di Australia. Lectora inspire diproduksi dan dirilis tahun 1999 oleh Trivantis Corporation yang didirikan oleh Timothy D. Loudermilk. Lectora digunakan untuk membuat website, konten e-learning interaktif, dan presentasi. Lectora juga memungkinkan untuk mengkonversi presentasi Microsoft Power Point ke konten $e$ learning. Konten yang dikembangkan dengan perangkat lunak Lectora dapat dipublikasikan ke berbagai 
output seperti HTML, single file executable, CD-ROM, maupun standar e-learning seperti SCORM dan AICC. Lectora kompatibel dengan berbagai sistem manajemen pembelajaran (Istiyanto, 2011:1).

Lectora Inspire merupakan software pengolah video animasi yang memiliki fitur beragam sehingga mampu menjadi media pembelajaran yang dapat disesuaikan dengan kebutuhan. Pembuatan video animasi juga dapat dilakukan secara offline sehingga tidak tergantung pada layanan internet, hal ini pastinya akan lebih memudahkan guru dalam membuat media pembelajaran ini.

\section{METODE}

Penelitian ini dilaksanakan di SMK Negeri 1 Percut Seituan, Jl. Kolam No.3 Kecamatan Percut Sei Tuan Kab. Deli Serdang, Sumatera Utara 20225, Kelas X Teknik Instalasi Penerangan Tenaga Listrik (TITL) Tahun Ajaran 2019/2020. Penelitian ini digolongkan pada penelitian pengembangan (Research and Development). Metode penelitian dan pengembangan adalah metode penelitian yang digunakan untuk menghasilkan produk tertentu, dan untuk dapat menghasilkan produk tersebut digunakan penelitian yang bersifat analisis kebutuhan (Sugiyono, 2012:407). Research and Development (R\&D) dipilih karena metode penelitian ini merupakan metode penelitian yang digunakan untuk menghasilkan produk tertentu dan menguji hasil produk tersebut. Metode ini dianggap tepat digunakan dalam penelitian ini karena pada dasarnya penelitian ini bertujuan untuk menghasilkan media pembelajaran menggunakan Lectora Inspire.

Produk pengembangan ini akan menghasilkan software atau program berupa multimedia interaktif yang berisi konten yang memuat materi dalam bentuk gambar, teks, audio, animasi, dan video. Model pengembangan yang digunakan dalam pengembangan multimedia interaktif ini adalah model pengembangan 4D (Define, Design, Develop, and Disseminate).

\section{Prosedur Pengembangan}

Prosedur pengembangan yang menjadi acuan dalam penelitian ini adalah model 4-D yang dikembangkan oleh Thiagarajan (dalam Endang Mulyaningsih, 2011:179-183). Model pengembangan 4-D terdiri atas 4 tahapan pengembangan, yaitu define (tahap pendefinisian), design (tahap perancangan), develop (tahap pengembangan), dan disseminate (tahap penyebarluasan). Tetapi penelitian ini hanya sampai pada tahap pengembangan dan tidak memakai tahap penyebaran (disseminate) karena pada tahap pengembangan (develop), tujuan penelitian telah tercapai dimana media pembelajaran yang dikembangkan telah diketahui sejauh mana kelayakannya untuk diterapkan dalam proses pembelajaran.

Berikut adalah penjabaran dari pengembangan 4-D yang disesuaikan dengan penelitian pengembangan multimedia interaktif :

1. Tahap pendefinisian (Define)

Menurut Thiagarajan (dalam Trianto, 2007:93) tujuan tahap ini adalah menetapkan dan mendefinisikan kebutuhan di dalam proses pembelajaran. Pada tahap define (pendefinisian) merupakan tahapan analisis dan identifikasi masalah untuk memperoleh berbagai informasi yang berkaitan dengan produk yang akan dikembangkan.

2. Tahap Perancangan (Design)

Tujuan dari tahap ini adalah untuk merancang perangkat pembelajaran yang akan dikembangkan sehingga diperoleh prototipe perangkat. Secara garis besar tahap perancangan ini meliputi tiga langkah yaitu pemilihan media, pemilihan format media dan desain awal media.

3. Tahap Pengembangan (Develop)

Tujuan tahap ini adalah menghasilkan produk yang sudah direvisi berdasarkan masukan dan saran dari para ahli. Tahap pengembangan ini meliputi validasi ahli dengan menggunakan instrumen yang diadaptasi dari Sriadhi (2018). Diketahui dari hasil validasi ahli kemudian dilakukan revisi sampai produk layak dan dapat digunakan sebagai bahan ajar. Penilaian atau validasi oleh ahli dapat ditentukan dengan kriteria kelayakan yang didapat dari rerata skor responden. Nilai rerata skor responden yang telah didapat kemudian dikonversikan sesuai tabel konversi kelayakan untuk mengetahui tingkat kelayakan modul pembelajaran menurut responden.

\section{Perancangan dan Pembuatan Produk}

Pada perancangan media pembelajaran multimedia interaktif lectora inspire dengan materi alat dan bahan kelistrikan elektromekanik menggunakan beberapa sumber buku dan internet sebagai panduan materi. 
Pembuatan sketsa produk dilakukan untuk menentukan konsep media interaktif yang akan dirancang dan menguraikan semua alur dari menu awal ke tampilan berikutnya secara lengkap.

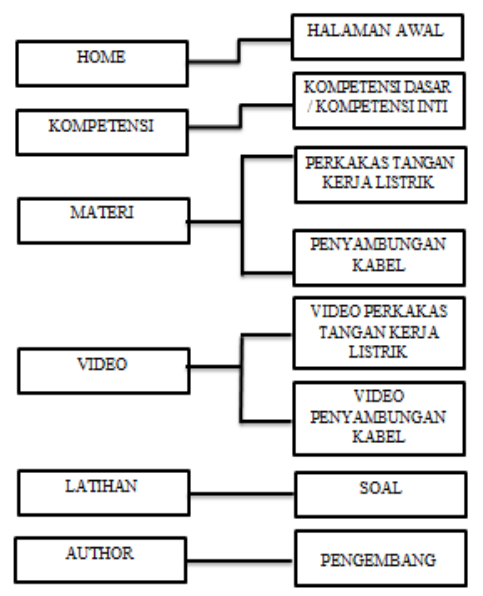

Gambar 1. Sketsa Produk

Setelah data diperoleh, selanjutnya adalah menganalisis data tersebut. Penelitian ini lebih menitikberatkan pada kelayakan media pembelajaran yang dirancang sebagai media pembelanjaran pada standar kompetensi materi alat dan bahan kelistrikan, sehingga data dianalisis dengan baik.

$\bar{X}=\frac{\sum X}{N}($ Sumber : Sriadhi, 2018)

Dimana :

$\boldsymbol{X}$ : skor kelayakan Coursware

$\sum \boldsymbol{X}:$ jumlah skor item

$\boldsymbol{N} \quad$ : jumlah item

Tabel 1. Interval Kriteria Penilaian

\begin{tabular}{|c|c|c|}
\hline NO & $\begin{array}{c}\text { INTERVAL } \\
\text { SKOR }\end{array}$ & INTERPRETASI \\
\hline 1. & $1.00-2.49$ & Tidak layak \\
\hline 2. & $2.50-3.32$ & Kurang layak \\
\hline 3. & $3.33-4.16$ & Layak \\
\hline 4. & $4.17-5.00$ & Sangat layak \\
\hline
\end{tabular}

\section{HASIL DAN PEMBAHASAN}

Hasil

Peneliti merancang media pembelajaran yang diajukan kepada siswa SMK Negeri 1 Percut Sei Tuan dalam bentuk multimedia interaktif. Media pembelajaran ini dibangun dalam bentuk multimedia interaktif bertujuan untuk mempermudah siswa dalam belajar dimana dapat digunakan dengan sangat mudah serta mempermudah siswa dalam menggambarkan suatu hal yang abstrak menjadi lebih kongkrit atau nyata. Dalam metode penelitian pengembangan ini, model yang digunakan adalah model 4-D yang dikembangkan oleh S. Thiagarajan, Dorothy S. Semmel, dan Melvyn I. Semmel (1974:5). Empat tahapan dalam model ini yaitu pendefinisian (define), perancangan (design), pengembangan (develop), dan penyebaran (dissiminate). Namun dalam prosedur pengembangan media pembelajaran multimedia interaktif Lectora Inspire ini model pengembangan 4D dilakukan sedikit modifikasi, yaitu penyederhanaan dari 4D menjadi 3D sehingga model yang digunakan yaitu pendefinisian (define), perancangan (design), dan pengembangan (develop). Tahap penyebaran (diseminate) tidak dilakukan karena pada tahap pengembangan (develop), tujuan penelitian telah tercapai dimana media pembelajaran yang dikembangkan telah diketahui sejauh mana kelayakannya untuk diterapkan dalam proses pembelajaran. 
1. Pendefinisian (define)

Menurut Thiagarajan (dalam Trianto, 2007:93) tujuan tahap ini adalah menetapkan dan mendefinisikan kebutuhan di dalam proses pembelajaran. Pada tahap define (pendefinisian) merupakan tahapan analisis dan identifikasi masalah untuk memperoleh berbagai informasi yang berkaitan dengan produk yang akan dikembangkan. Berdasarkan permasalahan yang ada, peneliti melakukan beberapa hal dalam analisis kebutuhan, yaitu:

a. Observasi kelas atau pengamatan kelas pada saat proses belajar mengajar sedang berlangsung di kelas X TIPTL. Berdasarkan observasi pada saat pembelajaran berlangsung, peserta didik cenderung pasif dan sering menjadi objek penerima informasi dari presentasi lisan guru. Dalam kebanyakan kegiatan belajar mengajar, guru sering menggunakan metode ceramah disertai dengan menulis materi pada papan tulis. Dibutuhkan suatu media pembelajaran yang diharapkan dapat menarik perhatian peserta didik lebih aktif dalam kegiatan pembelajaran. Maka dari itu, penelitian ini dilakukan dengan mengembangkan aplikasi Lectora Inspire. Adanya penelitian ini diharapkan dapat membantu guru dalam menentukan media pembelajaran yang tepat dan sesuai dengan kompetensi dasar dan standar kompetensi sehingga tujuan pembelajaran dapat tercapai.

b. Wawancara dilakukan kepada guru dan beberapa siswa pada mata pelajaran Pekerjaan Dasar Elektromekanik sehingga diketahui dasar penentuan media yang sesuai dengan kebutuhan. Dari wawancara yang telah dilakukan penulis, peserta didik cenderung pasif karena sistem pembelajaran yang monoton maka ditentukan materi-materi yang akan disajikan dalam pengembangan media pembelajaran dan diajarkan di kelas untuk meningkatkan pemahaman dan pengetahuan peserta didik yang beracuan pada kurikulum yang berlaku di SMK Negeri 1 Percut Sei Tuan.

Permasalahan yang diperoleh dari observasi dan wawancara ini kemudian dijadikan bahan acuan untuk memecahkan masalah tersebut. Adanya penelitian ini diharapkan dapat membantu guru dalam menentukan media pembelajaran yang tepat dan sesuai dengan kompetensi dasar dan standar kompetensi sehingga tujuan pembelajaran dapat tercapai.untuk mencapai tujuan tersebut, maka penulis memilih untuk mengembangkan media pembelajaran Lectora Inspire.

\section{Perancangan (design)}

Tujuan dari tahap ini adalah untuk merancang perangkat pembelajaran yang akan dikembangkan sehingga diperoleh prototipe perangkat. Secara garis besar tahap perancangan ini meliputi tiga langkah yaitu pemilihan media, pemilihan format media dan desain awal media.

\section{Pengembangan (Develop)}

Tujuan tahap ini adalah menghasilkan produk yang sudah direvisi berdasarkan masukan dan saran dari para ahli. Tahap pengembangan ini meliputi validasi ahli dengan menggunakan instrumen yang diadaptasi dari Sriadhi (2018). Diketahui dari hasil validasi ahli kemudian dilakukan revisi sampai produk layak dan dapat digunakan sebagai bahan ajar. Penilaian atau validasi oleh ahli dapat ditentukan dengan kriteria kelayakan yang didapat dari rerata skor responden. Nilai rerata skor responden yang telah didapat kemudian dikonversikan sesuai tabel konversi kelayakan untuk mengetahui tingkat kelayakan modul pembelajaran menurut responden.

a. Validasi Ahli

Untuk mengetahui kelayakan dari media pembelajaran Lectora Inspire, maka dilakukan validasi oleh ahli materi dan ahli media.

a) Validasi materi

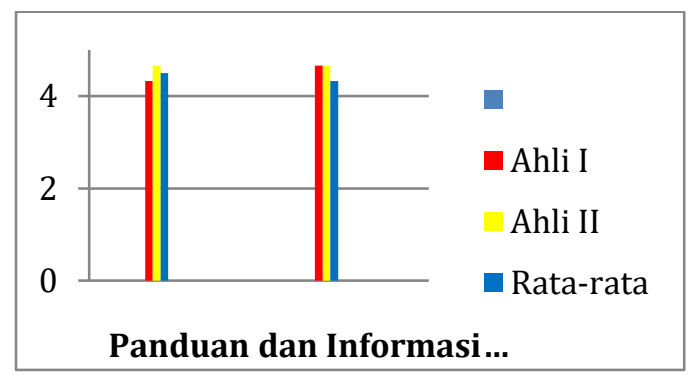

Gambar 2. Hasil Validasi Ahli Materi 
Berdasarkan tabel diatas hasil penilaian materi oleh ahli materi (ahli 1), ahli Bahasa (ahli 2) dan praktisi guru diketahui bahwa materi pelajaran mendapatkan rata-rata penilaian pada indikator Panduan Informasi sebesar 4,5 (Sangat Baik). Konten/Materi Multimedia sebesar 4,66 (Sangat Baik). Dan bila dirata-ratakan secara keseluruhan mendapatkan nilai 4,58 dan dapat dinyatakan "Sangat Baik".

b) Validasi media

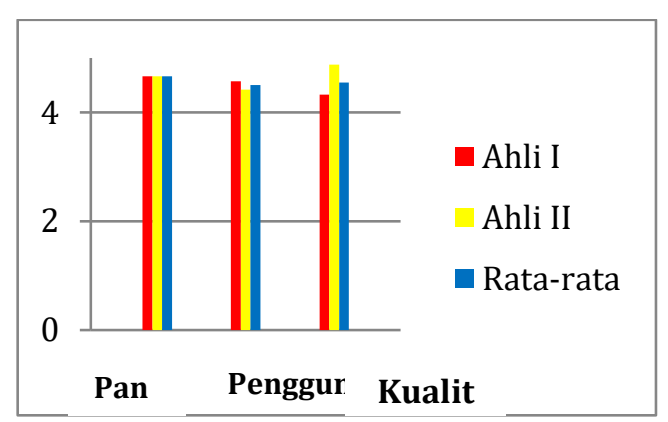

Gambar 3. Hasil Validasi Ahli Media

Berdasarkan tabel diatas hasil penilaian media oleh ahli media dan praktisi guru diketahui bahwa media mendapatkan rata-rata penilaian pada indikator Panduan Informasi sebesar 4,66 (Sangat Baik). Penggunaan Coursware sebesar 4,5 (Sangat Baik), dan Kualitas Estetika Paparan sebesar 4,55 (Sangat Baik). Dan bila dirata-ratakan secara keseluruhan mendapatkan nilai 4,57 dan dapat dinyatakan "Sangat Baik".

c) Validasi Praktisi

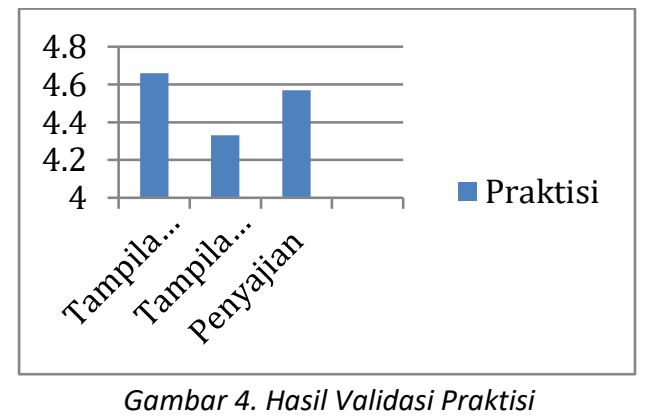

Berdasarkan tabel diatas hasil validasi media oleh praktisi diketahui bahwa media mendapatkan rata-rata penilaian pada indikator Tampilan Media sebesar 4,66 (Sangat Baik). Tampilan Bahan Ajar sebesar 4,33 (Sangat Baik), dan Penyajian sebesar 4,57 (Sangat Baik). Dan bila dirata-ratakan secara keseluruhan mendapatkan nilai $\mathbf{4 , 5 2}$ dan dapat dinyatakan "Sangat Baik".

4. Uji Coba Lapangan

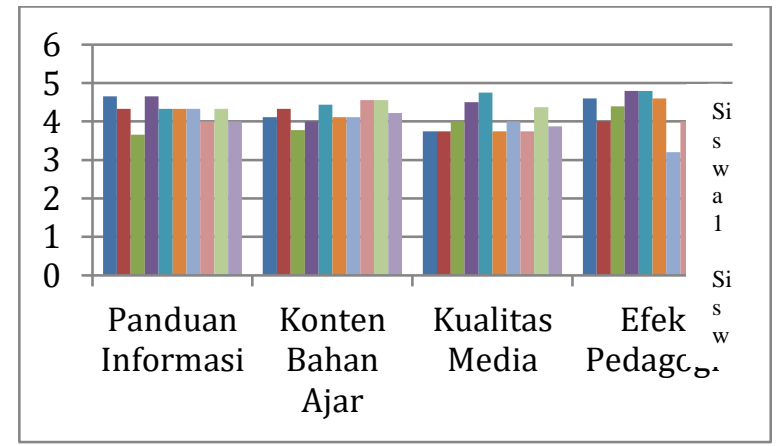

Gambar 5. Hasil Ujicoba Lapangan 
Berdasarkan tabel diatas hasil pengujian ini dapat dilihat bahwa hasil pengujian memiliki rata-rata penilaian pada indikator Panduan Informasi sebesar 4,26 (Sangat Baik). Indikator Konten Bahan Ajar sebesar 4,22 (Sangat Baik). Indikator Kualitas Media sebesar 4,05 (Baik). Indikator Efek Pedagogi sebesar 4,42 (Sangat Baik) dan bila dirata-ratakan secara keseluruhan sebesar 4,23 dan dikatergorikan "Sangat Baik".

\section{Pembahasan}

Penelitian ini diangkat dari permasalahan karena guru mata pelajaran Pekerjaan Dasar Elektromekanik lebih sering memberikan penjelasan materi pembelajaran dengan metode ceramah dan tidak adanya bahan ajar yang menjadi pegangan siswa sehingga peserta didik tidak dapat belajar secara mandiri.

Metode yang digunakan pada penelitian ini adalah metode Research and Development $(R \& D)$ dengan model 4D yang dikembangkan oleh S. Thiagarajan, Dorothy S. Semmel, dan Melvyn I. Semmel sebagai desain pembelajarannya. Empat tahapan dalam model ini yaitu pendefinisian (define), perancangan (design), pengembangan (develop), dan penyebaran (dessiminate). Namun dalam prosedur pengembangan media pembelajaran multimedia interaktif Lectora Inspire ini model pengembangan 4D dilakukan sedikit modifikasi, yaitu penyederhanaan dari 4D menjadi 3D sehingga model yang digunakan yaitu pendefinisian (define), perancangan (design), dan pengembangan (develop). Hal ini sesuai dengan tujuan penelitian yaitu untuk dapat mengetahui proses pengembangan dan kelayakan media pembelajaran multimedia interaktif lectora inspire mata pelajaran Pekerjaan Dasar Elektromekanik kelas X TIPTL SMK Negeri 1 Percut Sei Tuan.

Pada tahap-tahap dari penelitian pengembangan yang telah dilaksanakan, maka dihasilkan suatu pengembangan media pembelajaran yang divalidasi oleh validator yang terdiri dari 2 ahli materi dan 2 ahli media dengan menggunakan instrumen penelitian yang diadaptasi dari Sriadhi (2018). Hasil validasi dari ahli materi dan ahli media menunjukkan bahwa media pembelajaran Lectora Inspire layak digunakan/diterapkan dengan sedikit revisi dalam pembelajaran Pekerjaan Dasar Elektromekanik kelas $X$ TITL SMK Negeri 1 Percut Sei Tuan dengan dibuktikan pada penjelasan dibawah ini.

Berdasarkan data validasi yang diisi oleh ahli media dan ahli materi sebagai Validator, maka media pembelajaran ini dinyatakan memenuhi persyaratan dan layak digunakan sebagai pembelajaran dengan dibuktikan dengan nilai skor 4,57 dikategorikan "Sangat Layak" dari ahli media dan skor 4,58 dikategorikan "Sangat Layak" dari ahli materi.

Kemudian berdasarkan hasil uji coba produk yang dilakukan pada pengujian sebanyak 10 orang siswa kelas X TIPTL SMK Negeri 1 Percut Sei Tuan didapatkan rata-rata penilaian sebesar 4,23 dan dikategorikan "Sangat Layak".

\section{PENUTUP \\ Simpulan} bahwa :

Berdasarkan data hasil penelitian dan pembahasan yang telah diuraikan maka dapat disimpulkan

1. Pengembangan media pembelajaran multimedia interaktif Lectora Inspire menggunakan metode penelitian Research and Development $(R \& D)$ dengan model 4D sebagai desain pembelajarannya. Adapun langkah-langkah pada tahapan penelitian model 4D adalah define, design, develop, dan disseminate yang diadaptasi menjadi pendefinisian, perancangan, pengembangan, dan penyebaran. Tetapi tahap penyebaran (dessiminate) tidak dilakukan karena keterbatasan waktu dan pada tahap pengembangan (develop), tujuan penelitian telah tercapai dimana media pembelajaran yang dikembangkan telah diketahui sejauh mana kelayakannya untuk diterapkan dalam proses pembelajaran. Hal ini sesuai dengan tujuan penelitian yaitu untuk mengetahui proses pengembangan media pembelajaran multimedia interaktif Lectora Inspire mata pelajaran Pekerjaan Dasar Elektromekanik kelas X TIPTL SMK Negeri 1 Percut Sei Tuan.

2. Berdasarkan data validasi yang diisi oleh ahli media dan ahli materi sebagai Validator, maka media pembelajaran ini dinyatakan memenuhi persyaratan dan layak digunakan sebagai pembelajaran dengan dibuktikan dengan nilai skor 4,57 (Sangat Layak) dari ahli media dan skor 4,58 (Sangat Layak) dari ahli materi.

\section{Saran}


Berdasarkan hasil penelitian, pembahasan dan kesimpulan di atas, maka saran yang dapat diberikan pada penelitian ini adalah :

1. Guru di sekolah hendaknya memanfaatkan fasilitas di sekolah dan menggunakan media pembelajaran multimedia interaktif Lectora Inspire untuk meningkatkan pemahaman siswa dan motivasi belajar siswa

2. Guru disekolah harus mengembangkan kreativitasnya dalam membuat media pembelajaran untuk peserta didik dan lebih memanfaatkan media pembelajaran dalam kegiatan belajar mengajar namun peserta didik tetap dipantau dalam proses pembelajarannya.

\section{DAFTAR PUSTAKA}

Arsyad, Azhar. (2011). Media Pembelajaran. Jakarta: PT. RajaGrafindo Persada

Astutik, Mega., Rusimanto, P.W. (2016). Pengembangan Media Pembelajaran Multimedia Interaktif Berbantu Software Lectora Inspire untuk Meningkatkan Hasil Belajar Pada Mata Pelajaran Teknik Listrik di SMK Negeri 2 Surabaya. Teknik Elektro, Fakultas Teknik, Universitas Negeri Surabaya. Jurnal Pendidikan Teknik Elektro. Vol 05 No 01.

Hamalik, Oemar. (1994). Media Pendidikan. Bandung: Alumni

Istiyanto, (2011). Modul Pelatihan Lectora Authoring Tool, Pengenalan Fitur Lectora 3, Yogyakarta: BTKP DIY.

Mulyatiningsih, Endang. 2011. Metode Penelitian Terapan Bidang Pendidikan. Bandung: Alfabeta.

Mursid, R. (2013). Pengembangan Model Pembelajaran Berbasis Kompetensi :

Suatu Pendekatan Pembelajaran Praktik Berbasis Kompetensi Berorientasi Produksi Pada Pendidikan Teknik Mesin. Medan: Unimed Press

Noor, Muhammad. 2010. Media Pembelajaran Berbasis Teknologi. Jakarta: Multi Kreasi Satu Delapan. Padmo, Dewi., dkk. (2004). Peningkatan Kualitas Belajar Melalui Teknologi Pembelajaran. Jakarta: Pusat Teknologi Komunikasi dan Informasi Pendidikan.

Prawiradilaga, D. S dan Siregar, E. (2012). Mozaik Teknologi Pendidikan. Kencana: Prenada Media Group.

Riyanto, Yatim. (2014). Paradigma Baru Pembelajaran. Surabaya: Kencana.

Rusman. (2013). Metode-Metode Pembelajaran: Mengembangkan. Profesionalisme Guru. Jakarta: PT RajaGrafindo Persada.

Sadiman, A.S., Rahardjo, R., Haryono, A., dan Rahardjito. (2009). Media Pendidikan: Pengertian, Pengembangan, dan Pemanfaatannya. Jakarta: PT. Rajawali Pers.

Sobry Sutikno, M. 2009. Peran Dosen Dalam Membangkitkan Motivasi Belajar Mahasiswa. Bandung: Remaja Rosdakarya

Sriadhi, 2018. Instrumen Penilaian Multimedia Pembelajaran. Medan. Universitas Negeri Medan

Sugiyono. (2012). Metode Penelitian Kuantitatif Kualitatif dan R\&D. Bandung: Alfabeta

Susilana, Rudi. (2009). MEDIA PEMBELAJARAN: Hakikat, Pengembangan, Pemanfaatan, dan Penilaian. Bandung: Wacana Prima

Trianto, (2010). Mengembangkan Model Pembelajaran Tematik. Jakarta: PT. Prestasi Pustaka

Trianto, (2010).Mengembangkan Model Pembelajaran Inovatif-Progresif. Jakarta: Kencana.

Yoto., Zulkardi., Wiyono, Ketang. (2015). Pengembangan Multimedia Interaktif Pembelajaran Teori Kinetik Gas Berbantuan Lectora Inspire untuk Peserta Didik Sekolah Menengah Atas (SMA). Teknologi Pendidikan FKIP, Universitas Sriwijaya. Jurnal Inovasi dan Pembelajaran Fisika,. Vol 02 No 02.

Zuhri, M.S., Rizaleni, E.A. (2016). Pengembangan Media Lectora Inspire dengan Pendekatan Konstektual Pada Siswa SMA Kelas X. FPMIPATI, Universitas PGRI Semarang. Jurnal Pendidikan Matematika. ISSN Cetak: 2301-5314. 